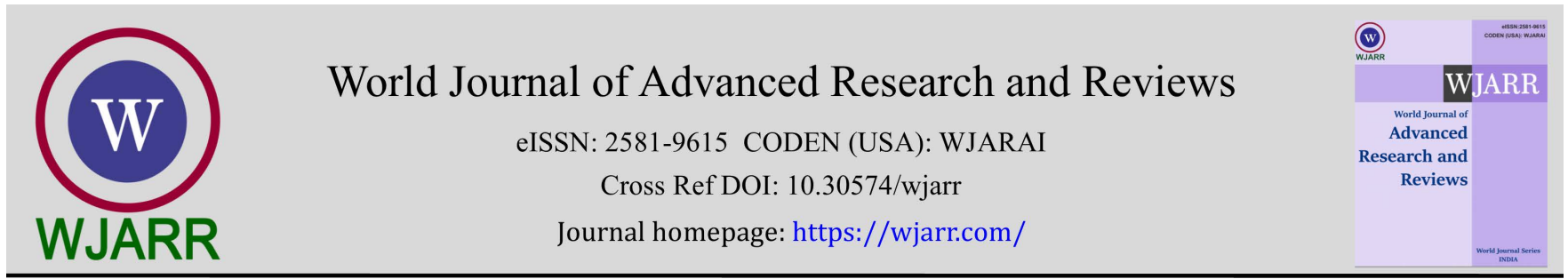

(RESEARCH ARTiClE)

\title{
Factors affecting neonatal birth weight in Sidotopo Wetan Health Centre: A cross- sectional study
}

\author{
Lila Amila 1, ${ }^{*}$, Ezrin Syariman bin Roslan ${ }^{1}$, Nabila ${ }^{1}$ and Widati Fatmaningrum ${ }^{2, *}$ \\ ${ }^{1}$ Faculty of Medicine, Universitas Airlangga, Surabaya, Indonesia. \\ 2 Department of Public Health, Faculty of Medicine, Universitas Airlangga, Surabaya, Indonesia.
}

World Journal of Advanced Research and Reviews, 2022, 13(01), 266-272

Publication history: Received on 01 December 2021; revised on 04 January 2022; accepted on 06 January 2022

Article DOI: https://doi.org/10.30574/wjarr.2022.13.1.0001

\begin{abstract}
Birth weight serves as an indicator of a newborn's health status. It is associated with mortality rate in the first year, developmental problems in childhood and risk of various diseases in adulthood. Even in modern era, it continues to be a health concern globally, especially in developing countries. In Indonesia, the prevalence of low birth weight has increased from 2013 to 2018, swaying further from the national target. Low birth weight is often caused by insufficient nutrients supplied by the mother to the fetus. In Indonesia, chronic energy deficiency status is diagnosed in the first antenatal care visit by measuring maternal middle-upper arm circumference with a cut-off point of $23.5 \mathrm{~cm}$. Meanwhile, iron level is measured via assessing hemoglobin level will be measured in the first antenatal care visit and in trimester III. This study aims to describe the factors that may influence neonatal birth weight. It is a quantitative study with a cross sectional approach conducted at Sidotopo Wetan Public Health Centre. 97 samples are collected from medical records and analysed using bivariate correlative test. Result shows that maternal age (0.20), chronic energy deficiency status (0.026) and antenatal care visit minimal of 4 times (0.49) increase the risk of low-birth-weight incidence. On the other hand, educational level, maternal parity and anemia status does not acts as risks. In conclusion, maternal age, energy status and visits to antenatal care acts as risk factors in causing low birth weight.
\end{abstract}

Keywords: Low Birth Weight; Risk Factors; Chronic Energy Deficiency; Maternal Age; Antenatal Care Visits

\section{Introduction}

Birth weight serves as an indicator of newborn's health. The birth weight is a reflection of materna capability to deliver nutrients to the fetus. In 2015, United Nation Children's Fund (UNICEF) has recorded the prevalence of low birth weight babies is $14.6 \%$. Although the prevalence is not as high in Indonesia, it remained concerning as it has increase to $6.2 \%$ in 2018. This incidence will impact upon nation's health as low birth weight babies are more vulnerable towards infections, immature lungs and breathing problems after delivery, and also contributes into a poorer diagnosis into the adulthood [1].

Fetal growth is influenced by the amount of provided by the placental circulation. Insufficient micro and macro nutrients will affect the availability of nutrients being transported to the fetus. In Indonesia, the favorite method used in diagnosing chronic energy deficiency (CED) is by measuring maternal middle-upper arm circumference with a cut-off point of $23.5 \mathrm{~cm}$. CED suggests lack of energy intake that occurred over a long period of time and reflects upon the maternal macronutrients. The prevalence of CED in pregnant women in Indonesia is recorded to be $16.99 \%$ and now is aiming for a new national target which is $10 \%$ by year $2025[2,3]$. The condition holds negative consequences for both the mother and the fetus, including anemia on maternal and baby, congenital malformation, low birth weight, hemorrhage and many more. Wijayanti [4] found that pregnant women with CED risks of having low birth weight babies

\footnotetext{
${ }^{*}$ Corresponding author: Widati Fatmaningrum

Department of Public Health, Faculty of Medicine, Universitas Airlangga, Surabaya, Indonesia.

Copyright $(2022$ Author(s) retain the copyright of this article. This article is published under the terms of the Creative Commons Attribution Liscense 4.0.
} 
is eight times higher than women without it. On the other hand, micronutrients also play a role in determining neonatal birth weight.

Gestational anemia is a physiological process of pregnancy as the demand of blood circulation increases. The mother is required not to only regulates the blood circulation for herself, but also for the fetus. To compensates the volume demand, the body increases the plasma volume progressively that may reach up to $50 \%$. This will increase the plasma volume to red blood cell ratio, causing hypervolemia. This condition often peaked in late second trimester and peaked at week 30-34 weeks [5,6]. Hypervolemia is itself will benefit the mother as it decreases the viscosity of the blood. Blood pumped from the heart not only in maternal peripheral circulation, but also has to reach for placental perfusion and vascular space of uterus, mammae, muscle, skin and kidney. Hypervolemia eases the heart's burden to increasing cardiac output to meet all the oxygen demands stillbirths [5,7). Normally, anemia will not occur in trimester III because the red blood cells production increases and matches the blood volume. However, insufficient of iron, vitamin b12 and folate may lead to anemia [8].

Maternal characteristics also act as a risk factor for low birth weight. Factors may include maternal age, educational level, number of antenatal care visits and maternal parity. Pregnant with age of below than 20 causes the reproductive organ not to mature biologically, hence may be hard to expand. Similar to that, pregnancy at the age of above 35 years old causes uterus and cervix to be more rigid which may also risk of causing low birth weight [9].

In view of what has been mentioned above, the study is interested to find the factors that has a significant relationship with neonatal birth weight as an effort in reducing the risks on each pregnant women and ultimately aiming to reduce the prevalence of low birth weight in Indonesia.

\section{Material and methods}

The study is conducted from January to December 2021 at Sidotopo Wetan Public Health Centre. By using Cochrane's and Snedecor's formula, minimal samples needed in this study is 22 samples, assuming prevalence of low birth weight is $6.2 \%$ [2]. Samples are taken from medical records ranged from January 2018 to December 2020 via purposive sampling. The inclusion criteria are maternal that perform antenatal care visits and complete parturition at Sidotopo Wetan Public Health Centre, while the exclusion criteria are twin birth, maternal with short stature and pregnancy gap of lower than 24 months. Only the data that met the inclusion and exclusion criteria were recorded. Data are then analyzed using SPSS 25 and run under Mann Whitney U and Kruskal Wallis test to determine its association as risk factor for low birth weight.

\section{Results and discussion}

A total of 97 medical records were collected for the study. Data that were taken was limited to the information recorded in the medical record hence does not cover some aspects such as income level, physical activity and comorbidities.

\subsection{Maternal Age towards Neonatal Birth Weight}

Table 1 shows that most pregnant women aged between 20 to 35 years old $(91.75 \%)$. This is the recommended age to bear a child as the mother often mature biologically and psychologically at this age. Despites that, all 7 low birth weight babies were born by maternal in this age (100\%). The youngest women aged 17 years old, while the eldest is 39 years old. There is a significant relationship between maternal age and neonatal birth weight.

Despites all babies with low birth weight is born by maternal aged between 20 to 35 years old, analysis shows that there is a relationship between maternal age and neonatal birth weight. This is because normally, women's reproductive organs will only mature biologically and be able to adapt towards pregnancy by the age of 20 . Immature uterus will cause less blood to be supplied towards the cervix and uterus, hence also reduce the nutrition supply to the fetus. Meanwhile, after the age of 35, reproductive organs experience changes within the inner tissues and becomes more rigid. Therefore, it is harder for the uterus to expand, and may cause other complications such as hypertension, premature rupture of membranes and hemorrhage [9].

This finding is aligned with a study conducted by Alya dan U'budiyah in Aceh [10], where there is maternal age increases the risk of low birth weight up to six times (OR 6.163, p=0.000). In addition, Marie et al [9] also found that teenagers and women in advanced age has a significant increased rate of prematurity. However, this is not aligned with study by Pertiwi et al [11], where no relationship was found between maternal age and low birth weight. Though maternal age 
acts as a risk of low birth weight, it is not the main factor of low birth weight, as there is a need to also consider other the factors $[12,13)$.

Table 1 Analysis of Maternal Age against Low Birth Weight

\begin{tabular}{|l|c|c|c|c|c|}
\hline \multirow{2}{*}{ Variables } & & \multicolumn{2}{|c|}{ Category } & \multirow{2}{*}{$p$} \\
\cline { 2 - 5 } & & Low Birth Weight & Normal Birth Weight & \\
\hline \multirow{4}{*}{ Age } & $>20$ & 0 & 2 & 2 & \multirow{3}{*}{0.020} \\
\cline { 2 - 5 } & $20-35$ & 7 & 82 & 89 & \\
\cline { 2 - 5 } & $>35$ & 0 & 6 & 6 & \\
\hline Total & & 7 & 90 & 97 & \\
\hline
\end{tabular}

\subsection{Educational Level towards Neonatal Birth Weight}

Maternal educational level is shown in table 2. Education level may, but not always reflect upon maternal knowledge on health, habits and ability to learn an information. Most samples are high school and equivalent graduates (42.27\%) and from 41 of them, only 2 babies (4.88\%) were found to be low birth weight. The incidence of low birth weight in other level of education is $7.41 \%$ in primary school graduates, $4.76 \%$ in middle school graduates and $28.57 \%$ in women with diploma or above qualifications. The p value attained was 0.265 , indicating there is no significant relationship between maternal level of education and neonatal birth weight.

Analysis found that there is no correlation between maternal level of education and neonatal birth weight ( $p=0.265$ ). This is because maternal educational level does not mirrors their knowledge regarding health and pregnancy. Knowledge is not only attained through formal education, but also through experiences and specific to the individual needs [14]. This is also reinforced a find that formal education does not affect the usage of 'Mother and Child Health' book [15]. Sholiha and Sumarni [16] mentions that maternal knowledge upon health is also influenced by factor other than formal education, but also capability to access information via internet or midwives during antenatal care visits [16]. However, this is opposed study by Untari [17] where education level has a significant in causing low birth weight, due to educational level mirrors the person's ability to perception to be open to an information, differentiate the more rational information and increase their ability to gain knowledge.

Table 2 Analysis of Maternal Educational Level against Low Birth Weight

\begin{tabular}{|c|c|c|c|c|c|}
\hline & \multirow{2}{*}{ Variables } & \multicolumn{2}{|c|}{ Category } & \multirow[b]{2}{*}{ Total } & \multirow{2}{*}{$\mathbf{p}$} \\
\hline & & Low Birth Weight & Normal Birth Weight & & \\
\hline \multirow{4}{*}{$\begin{array}{l}\text { Educational } \\
\text { Level }\end{array}$} & Primary School & 2 & 25 & 27 & \multirow{4}{*}{0.265} \\
\hline & Middle School & 1 & 21 & 22 & \\
\hline & High School and Equivalent & 2 & 39 & 41 & \\
\hline & Diploma and above & 2 & 5 & 7 & \\
\hline Total & & 7 & 90 & 97 & \\
\hline
\end{tabular}

\subsection{Maternal Occupation towards Neonatal Birth Weight}

Majority of the women are working as a housewife (71.13\%), 15 samples working independently (15.46\%), leaving the rest working in a workforce. In some cases, women's occupation may reflect upon the family's income level as they will contribute to the family income. Majority of the low birth weight babies were born in maternal working as a housewife $(57.14 \%)$. However, this is only $5.80 \%$ of total delivery from the housewives. Kruskal Wallis test shows a palue of 0.804 , showing that there is no relationship between maternal occupation and neonatal birth weight.

Data shows that maternal occupation has no impact upon the occurrence of low birth weight. This study is aligned with study conducted in Kuningan by Rahim and Muharry [18], which also found that there is no relationship between maternal occupation and neonatal birth weight. However, this does not align with study by local studies where it was found that working may cause lowers neonatal birth weight as it requires maternal to perform physical activity over a 
long period of time $(\mathrm{p}=0.018)[19,20]$. In another hand, a study found that working while pregnancy may act as a protection factor by reducing the risk of low birth weight by 0.098 [21]

Table 3 Analysis of Maternal Parity against Low Birth Weight

\begin{tabular}{|l|l|c|c|c|c|}
\hline \multirow{2}{*}{\multicolumn{2}{|c|}{ Variables }} & \multicolumn{3}{c|}{ Category } & \multirow{2}{*}{ p } \\
\cline { 3 - 6 } & Low Birth Weight & Normal Birth Weight & Total & \\
\hline \multirow{3}{*}{ Occupation } & Housewife & 4 & 65 & 69 & \\
\cline { 2 - 5 } & Independent & 1 & 14 & 15 & 0.804 \\
\cline { 2 - 5 } & Others & 2 & 11 & 13 & \\
\hline Total & & 7 & 90 & 97 & \\
\hline
\end{tabular}

\subsection{Maternal Parity towards Neonatal Birth Weight}

Table 4 shows the maternal parity or the number of pregnancies the women is under. $20.62 \%$ of the population is undergoing their first pregnancy, most being in the $2^{\text {nd }}$ pregnancy $(36.05 \%)$ and the least in their $5^{\text {th }}$ pregnancy (1.03\%). $P$ value achieved was 0.148 , showing that there is no relationship between maternal parity and neonatal birth weight.

Maternal parity is split into three, primiparity, multiparity (2-4 children) and grandeparity ( $\geq 5$ parity). This study found that maternal parity has no significant relationship upon neonatal birth weight $(\mathrm{p}=0.148)$. This study is aligned with study found conducted by Susanti et al [22] where the p value found was 0.825, indicating it has no significant relationship with low birth weight. This is does not align with study conducted in Padang by Mahayana et al [23] that mentioned high parity will cause endometrium to become thin, reduce in quality and acts as a risk factor of low birth weight $(\mathrm{p}=0.022)$.

Table 4 Analysis of Maternal Parity against Low Birth Weight

\begin{tabular}{|c|c|c|c|c|c|}
\hline \multirow{2}{*}{\multicolumn{2}{|c|}{ Variables }} & \multicolumn{2}{|l|}{ Category } & \multirow[b]{2}{*}{ Total } & \multirow{2}{*}{$\mathbf{p}$} \\
\hline & & Low Birth Weight & Normal Birth Weight & & \\
\hline \multirow{5}{*}{ Maternal Parity } & 1 & 2 & 18 & 20 & \multirow{5}{*}{0.148} \\
\hline & 2 & 3 & 32 & 35 & \\
\hline & 3 & 1 & 27 & 28 & \\
\hline & 4 & 1 & 12 & 13 & \\
\hline & 5 & 0 & 1 & 1 & \\
\hline Total & & 7 & 90 & 97 & \\
\hline
\end{tabular}

\subsection{Antenatal Care Visits towards Neonatal Birth Weight}

In Indonesia, maternal is recommended to perform at least 4 antenatal care visits in total according to the 'Mother and Child Health' Book [3]. Majority of the women have completed all 4 visits, and some even more. The highest amounts of visits performed is total of 13 visits. Data shows that $71.4 \%$ low birth weight babies were born by women with inadequate number of visits. P value attained by Mann Whitney test was 0.049 , means that there is a significant relationship between the number of antenatal care visits and neonatal birth weight.

In Indonesia, Ministry of Health recommended pregnant women to perform at least 4 times throughout the pregnancy, once in trimester I and II and twice in trimester III [3]. This has been updated in the latest version in 2021, increasing the recommended antenatal care visits to 6 times per pregnancy. This study found that there is a significant relationship with neonatal birth weight (0.049). This founding is aligned with a systematical review conducted by Kusumawati [12] where two journals were found to have significant relationship with low birth weight with OR of 1,711 and 52,111, with a minimal of 4 visits. Antenatal care visits are very important for pregnant women as it helps them to take care of their physical and mental wellbeing, educating, detecting abnormalities, such that regular antenatal care visit will help 
quickly resolve any risks of causing abnormalities. This study does not align with study by Perwiraningtyas et al [11] as they found there is no significant relationship between antenatal care and low birth weight.

Table 5 Analysis of Antenatal Care Visits against Low Birth Weight

\begin{tabular}{|l|c|c|c|c|c|}
\hline \multirow{2}{*}{\multicolumn{2}{|c|}{ Variables }} & \multicolumn{3}{|c|}{ Category } & \multirow{2}{*}{ p } \\
\cline { 3 - 6 } \multicolumn{2}{|c|}{} & Low Birth Weight & Normal Birth Weight & Total & \\
\hline \multirow{3}{*}{ Antenatal Care Visits } & $<4$ & 5 & 21 & 26 & \multirow{2}{*}{0.049} \\
\cline { 2 - 5 } & $\geq 4$ & 2 & 69 & 71 & \\
\hline Total & & 7 & 90 & 97 & \\
\hline
\end{tabular}

\subsection{Anemia Status in Trimester III towards Neonatal Birth Weight}

$53.61 \%$ of the samples were found to have anemia, where $36.08 \%$ has mild anemia and $17.53 \%$ with moderate anemia. This prevalence is higher than the number recorded by Ministry of Health Indonesia in the annual health report, which is 48.9\% [15]. 3 of 7 low birth weight babies were born by both women with normal haemoglobin level and mild anemia. Analysis shows p value of 0.293 , refers that there is no significant relationship between maternal anemia status in trimester III and neonatal birth weight.

In Indonesia, maternal haemoglobin is measured twice throughout pregnancy, which is once during the first antenatal care visit, and once in trimester III at a public health centre. Analysis shown that haemoglobin level in trimester III does have a significant impact upon neonatal birth weight $(\mathrm{p}=0.293)$. This is aligned with the findings of a systematical review and meta-analysis by Rahmati et al [24] that found that only the first trimester has a significant impact upon incidence of low birth weight. However, this is opposed by systematic literature review by Murtiningsih et al [25] where it is found that anemia in trimester II and III affect low birth weight and premature births, highest risk being in trimester III.

Table 6 Analysis of Anemia Status in Trimester III against Low Birth Weight

\begin{tabular}{|c|c|c|c|c|c|}
\hline \multirow{2}{*}{\multicolumn{2}{|c|}{ Variables }} & \multicolumn{2}{|c|}{ Category } & \multirow[b]{2}{*}{ Total } & \multirow{2}{*}{$\mathbf{p}$} \\
\hline & & Low Birth Weight & Normal Birth Weight & & \\
\hline \multirow{3}{*}{ Anemia Status } & Non-anemia & 3 & 42 & 45 & \multirow{3}{*}{0.293} \\
\hline & Mild Anemia & 1 & 32 & 35 & \\
\hline & Moderate Anemia & 1 & 16 & 17 & \\
\hline Total & & 7 & 90 & 97 & \\
\hline
\end{tabular}

\subsection{Chronic Energy Deficiency Status towards Neonatal Birth Weight}

$25.97 \%$ of the pregnant women were found to experience chronic energy deficiency. The prevalence is higher than the recorded data by Ministry of Health of Indonesia in 2018, which is $17.3 \%$ [2]. 7.79\% of maternal without chronic energy deficiency gave birth to low birth weight babies, while the prevalence is only $5 \%$ in maternal with chronic energy deficiency

$\mathrm{P}$ value attained on analysis is 0.026 , indicating that there is a relationship of chronic energy deficiency status and neonatal birth weight. This study is aligned with study conducted in North Sulawesi by Simuaty et al [26] where the risk of low birth weight is up to four times. Chronic energy deficiency status refers to the imbalance nutritional status and may result in decrease of blood volume. Heart ejection fraction will drop, causing less blood to be transferred to the placenta. The placenta will become smaller in size as compared to a normal placenta and interfere with the oxygen and nutrition circulation of the baby. Fetus growth is interrupted and may result in LBW. This study is not aligned with a study from South Denpasar by Prabayukti [27] as it is theorized that measuring maternal middle-upper arm circumference is useful in screening for protein and energy malnutrition. Therefore, it is still possible for the maternal to have adequate micronutrients [28]. 
World Journal of Advanced Research and Reviews, 2022, 13(01), 266-272

Table 7 Analysis of Chronic Energy Deficiency Status against Low Birth Weight

\begin{tabular}{|l|c|c|c|c|c|}
\hline \multirow{2}{*}{ Variables } & \multicolumn{2}{c|}{ Category } & & \multirow{2}{*}{ p } \\
\cline { 3 - 6 } \multicolumn{2}{|c|}{} & Low Birth Weight & Normal Birth Weight & Total & \\
\hline \multirow{2}{*}{ Chronic Energy Deficiency } & $<23.5 \mathrm{~cm}$ & 1 & 19 & 20 & \multirow{2}{*}{0.026} \\
\cline { 2 - 6 } & $\geq 23.5 \mathrm{~cm}$ & 6 & 71 & 77 & \\
\hline Total & & 7 & 90 & 97 & \\
\hline
\end{tabular}

\section{Conclusion}

The study found maternal age, chronic energy deficiency status and antenatal care visits plays a role in determining neonatal birth weight. In conclusion, it is important for understand the important of their body and nutritional level's condition before getting into pregnancy. Consulting to the experts via antenatal care visits will assist the mother not only to ease her concerns but also ensure an optimal pregnancy for both the maternal and the baby.

\section{Compliance with ethical standards}

\section{Acknowledgments}

We would like to thank Surabaya Public Health Office, Sidotopo Wetan Public Health Centre and all other parties that has contributed in assisting to complete this article.

\section{Disclosure of conflict of interest}

There is no conflict of interest in this study.

\section{Statement of ethical approval}

This study implemented the principle of Helsinki Declaration and has received an ethical certificate from Research Ethical Committee of Universitas Airlangga. Surabaya Public Health Office has given a letter of approval to conduct the study and the letter was handed over to Sidotopo Wetan Public Health Centre.

\section{Statement of informed consent}

This study uses second hand data attained from medical records, hence no direct inform consent from the patients are required.

\section{References}

[1] Predengast AJ, Humprey JH. The stunting syndrome in developing countries. Paediatrics and international Child Health. 2014; 34(4): 250-265.

[2] Ministry of Health of the Republic of Indonesia, 2018, Main Result of Basic Health Research (Riskesdas). 2018: 19.

[3] Ministry of Health of the Republic of Indonesia, 2018. Work Report of Directorate General of Public Health. 2020

[4] Wijayanti YT. Anemia and Chronic Energy Deficiency Throughout Pregnancy Increases Incidence of Low Birth Weight (Case Control Study). Jurnal Kesehatan Metro Sai Wawai. 2018; 11(2): 92-98.

[5] Akinlaja O. Hematological Changes in Pregnancy - The Preparation for Intrapartum Blood Loss. Obstetrics \& Gynecology International Journal. 2016; 4(3).

[6] Soma-Pillay P, Nelson-Piercy C, Tolppanen H, Mebazaa A. Physiological changes in pregnancy. Cardiovascular Journal of Africa, [online]. 2016; 27(2): 89-94.

[7] Budiarti A. Physiology and Pathology during Pregnancy. Yogyakarta. Nuha Medika. 2009.

[8] Pathak P, Kapil YK, Yajnik CS, Kapoor SK, Dwivedi SN, Singh R. Food and Nutrition Bulletin. 2007; 28(4): $435-438$. 
[9] Purwanto AD. Factor Correlated with Incidence of Low birth Weight Cases. Jurnal Berkala Epidemiologi. 2016; 4(3): 349.

[10] Alya D, U'budiyah. Factors Associated with Low Birth Weight in Mother and Child Hospital in Aceh City Year 2013. Thesis of Midwifery Diploma Programme Study. STIKes Ubudiyah Aceh City. 2014.

[11] Perwiraningtyas P, Ariani NL, Anggraini CY. Analysis of Risk Factors of Low-Birth-Weight JNC. 2020; 3(3): 212 220.

[12] Kusumawati E. A Systematic Review against Risk Factors on The Low Weight Birth Incidence in Indonesia, Journal of Health Science and Prevention. 2017; 1(1): 38-44.

[13] Fortey A. dan Whitone EW. Midwifery Knowledge: Pathology and Physiology of Labor. Yogyakarta: Yayasan Essential Medika. 2010.

[14] Swabsburg Russell C, Asih Yasmin, Waluyo Agung, Ester. Pengembangan Staf Keperawatan. 2001.

[15] Seprinawati G. Relationship between Education Level and Knowledge Level with the Utilization of Mother and Child Hleath Handbook by Mothers of Toddlers in the Assisted Areas of the Faculty of Public Health in 2019. Thesis of Public Health Diploma Programme. Universitas Andalas. 2019.

[16] Sholhiah H, Sumarni S. Analisis Reisko Kejadian Berat Lahir Rnedah (BBLR) pada Primigravida. Media Gizi Indonesia. 2015; 10(1): 57-63.

[17] Untari S. Maternal Knowledge regarding Factors Causing Low Birth Weight in Grobogan District. Jurnal Ilmiah Kesehatan. 2016; 8(2): 85-88.

[18] Rahim FK, Muharry A. Relationship between Mother's Characteristics and LBW Incidence in Kuningan District. Health Sciences journal. 2018; 9(2): 125-130.

[19] Puspitasari R. Relationship of Maternal Characteristics Education Level and Mother's Occupation with Low Birth Weight Babies at PKU Muhammadiyah Bantul LBW Hospital in Kuningan District.. Thesis of Midwifery Diploma Programme. Aisyiyah Institute of Health Science. Yogyakarta. 2014.

[20] Yuliva, Ismai D, Rumekti D. Relationship between Mother's Occupational Status and Baby's Birth Weight at Dr. M. Djamil Padang. Berita Kedokteran Masyarakat. 2009; 25(2): 96-108.

[21] Sandra SR, Iga TW. Risk Factors for Low Birth Weight Incidence in the Work Area of the Gianyar Public Health Integrated Service Unit II. Thesis of Medical Bachelor Programme. Universitas Udayana. 2013.

[22] Susanti DI, Rahmawati A, Arum DNS. Factors Associated with the Incidence of Low Birth Weight Babies in Wonosari Hospital, Gunung Kidul Regency in 2016. Thesis of Midwifery. Health Polytechnic Yogyakarta. 2016.

[23] Mahayana SAS, Chundrayetti E and Yulistini. Risk Factors Affecting the Incidence of LBW in Dr. RSUP. M. Djamil Padang. Jurnal Kesehatan Andalas . 2015; 4(3): 5.

[24] Rahmati S, Delpishe A, Azami M, Hafezi Ahmadi MR, Sayehmiri K. Maternal Anemia during pregnancy and infant low birth weight: A systematic review and Meta-analysis. International journal of reproductive biomedicine (Yazd, Iran). 2017; 15(3): 125-134.

[25] Murtiningsih D, Khofiyah N, Rokhanawati D. Anemia In Each Trimester with Low Birth Weight: A Systematic Literature Review. International Respati Health Conference (IRHC). 2019; 1: 955-962.

[26] Simuaty, Restu S. Maternal Chronic Energy Deficiency and Low Birth Weight. Jurnal Husada Mahakam. 2016; 4(3): 162-170.

[27] Prabayukti A. The Relationship Between Chronic Energy Deficiency and the Incidence of Low Birth Weight at Puskesmas I South Denpasar in 2019. Thesis of Midwifery Diploma Programme. Health Polytechnic Denpasar. 2019.

[28] Fatimah S, Yuliani NT. The Relationship between Chronic Energy Deficiency in Pregnant Women and the Incidence of Low Birth Weight in the Work Area of the Rajadesa Health Center in 2019. Thesis of Midwifery Diploma Program, Faculty of Health, Galuh University. 2019. 